\title{
An Exploration of Consumer's Concern Towards Plus Size Fashion Business for Cost and Profitability Projection
}

\author{
Ilham Pristaka Yudha, Asep Darmansyah, and Acip Sutardi
}

\begin{abstract}
Plus Size is strongly associated with Obesity and it results special needs and specifications. For Plus Size fashion business, the plus-size clothing has been a very attractive. However, dissatisfaction was greatest related to the large-size group when studying size availability, then the problem is not just that but rather be like with the shopping environment. So that, cost and profitability of companies are big issues and the company needs to have effective cost from manufacturing without neglecting product quality but still gaining high profitability. This research is aimed to explore consumer's concern in plus size fashion business, therefore to project cost and profitability focused in male plus size pants business according to consumer's concern. This research only focuses on male plus size consumer aged more than equal 18 - 60 years old in Bandung City using direct deep interview for plus size user. Using five variables understanding of "Plus Size Fashion", consumer's buying process, price consciousness, productrelated and non-product-related factor, to ease the researcher exploring consumer concerns in Plus Size Fashion. Those are then broken down into special classification to design the value proposition canvas as the foundation to project cost and profitability. In addition, comparing to the concept of current plus size business, the researcher recommends the to shift another pants' type product. For services given, just focus on the customization and quality warranty. The plus size user prefers offline but there is still possibility to sell online.
\end{abstract}

Index Terms-Plus Size Fashion, Plus Size User, Consumer's concern, Cost, and Profitability,

\section{INTRODUCTION}

[1] says that dissatisfaction was greatest related to the large-size group when studying size availability, pricing, colors, style selection and fit. However, "the problem is not just with the variety of sizes and styling on offer but rather be like with their role in providing overall fashion content, fit and the shopping environment" [2]. the sizing and designing pattern challenge may lead another challenge for local plus size fashion industry such as unsteady monthly revenue, small revenue upscaling, pricing strategy and uniqueness identity where at this point there are some local companies in the small or micro business which are struggling to have high company's profitably. In addition, this is aimed to be along with fulfilling consumer's expectation and to compete both in local and global plus size industry. So that, in this research,

Published on August 7, 2019.

Ilham Pristaka Yudha is with School of Business and Management, Institut Teknologi Bandung, Jalan Ganesha no.10, 40132, Bandung, West Java, Indonesia (e-mail: ilham.pristaka@sbm-itb.ac.id)

Asep Darmansyah is with School of Business and Management, Institut Teknologi Bandung, Jalan Ganesha no.10, 40132, Bandung, West Java, Indonesia (e-mail: asep.darmansyah@sbm-itb.ac.id) these are the objectives to fulfill the study in the plus size business industry:

1. Identifying the consumer's concern towards plus size fashion business.

2. Identifying the need of product and service in male plus size pants according to consumer's concern.

3. Projecting cost and profitability in male plus size pants business according to consumer's concern.

\section{Methodology}

This research is aimed to explore consumer's concern towards plus size fashion business in order to project cost and profitability. The data collection is obtained through depthinterview and therefore it will be analyzed for the need of product and service in plus size fashion. Related to data collection, this research only focuses on male plus size consumer aged more than equal $18-60$ years old in Bandung City. The result of depth-interview is expected to create the ideal of male plus size pants by using the value proposition canvas. Starting profitability projection is meant to see how business's ability in generating profit [3]. According to the values proposition canvas, the product needed have been known. The total expenses and cost have been stated above. So that understanding the cost through Cost structure is needed to be analyzed again through deciding pricing strategy that is linked to selling price and Pro Forma Statements. Pro statements require income statements and sales forecast can be from past historical data or obtained from the benchmarking of the same type of firm [4]. A variety assumption must also be made.

\section{Data Collection}

According to [5] that semi- structured interview is the best way for the researcher to conduct an explanatory research. Before using the semi-structured interview, the researcher needs to generate the interview guideline first and then during the interview is not totally depend on the order of the questions that has been structured before. The purpose of this method is to ensure that the objective of the interview could be achieved without limiting the respondents' opinion and perspective. According to [6] the ideal number of respondents or informants to do the qualitative approach are 10 people. Hence, the researcher will also do in-depth interview method to 10 different respondents. Those 10 different respondents

Acip Sutardi is with School of Business and Management, Institut Teknologi Bandung, Jalan Ganesha no.10, 40132, Bandung, West Java, Indonesia (e-mail: acip.sutardi@sbm-itb.ac.id) 
are focused on male who have plus size body. In addition, the decision who will be interviewed or simply the respondents, the researcher use a judgement sampling. It is defined as sampling techniques that performed based on the specified target elements which are tailored to the objectives or research problem.

\section{Data Analysis}

This research focused to explore the consumer's concern in plus size fashion which have effect on cost and profitability. To explore all the considerations, the researcher has found some literature to strengthen this research method from [7]. This research consists of two major processes to analyze the data collected which are transcript and coding.

\section{Triangulation Method}

This research is done through a triangulation because the researcher wants to increase the level of confidence in the data collection and also avoid the potential biases from a single methodology which may avoid subjectivity in qualitative approach [8]. The triangulation is done by:

- Asking about the data collection and results from interview to the lecturer as the academician as well as the business' mentor as the practitioners.

- The reliability of the results from this research is done through the repeatable interview in order to get the saturation of the respondent's answer which means the respondents have same answers for same questions. So that, the researcher is sure about the reliability of the result from the in-depth interview.

\section{Data Mapping}

This is the process where the researcher formulates the results of selective coding in data analysis. The formulation is formed into some models or matrix simply like Value proposition canvas for product and service. Thus, the ideal plus size fashion product according to consumer's concern through formulation value proposition canvas that will be used to project cost and profitability as the recommendation.

\section{Projected Cost of Goods Sold}

This is the process where the researcher formulates the results of selective coding in data analysis. The formulation is formed into some models or matrix simply like Value proposition canvas for product and service. Thus, the ideal plus size fashion product according to consumer's concern through formulation value proposition canvas that will be used to project cost and profitability as the recommendation.

\section{Pricing Strategy}

One interesting pricing strategy is Psychological price setting [9] using of number 9 which is so the price drops below a rounded number. The difference between the price 9,99 and 10 is not big and the consumer perceives the difference as being far bigger because by reading from left to right which significantly reduces overall perception of the price.

\section{Break-even Analysis}

Break-even point analysis is designed as measurement system for calculating the margin of safety. According to [10] in the book entitled Managerial Accounting: Concept for planning, Control, Decision Making $15^{\text {th }}$ Edition which says that The Break- even analysis consists of two approaches called the equation method and unit contribution method. It is therefore, the researcher decided to use the unit contribution method which is actually just a variation of the equation method already described. The approaches put on the idea discussed earlier that each unit sold provides a certain amount of contribution margin which covers fixed cost [10]. For instance, it's a way to how a project could be profitable by equating the total revenues and total expenses. There are some different uses for the equation but it is all about managerial accounting and cost management.

\section{Pro Forma Statements}

Profitability is defined as the ability for a company to generate profit. So that understanding the cost through Cost structure is needed to be analyzed again through deciding pricing strategy that is linked to selling price and Pro Forma Statements. Therefore, the approaches for estimating the pro forma statements are all based on the belief that financial relationship reflected in the past experience and not changing the coming period. Pro statements require income statements and sales forecast can be from past historical data or obtained from the benchmarking of the same type of firm [4]. A variety assumption must also be made.

\section{Results}

\section{A. The Understanding of "Plus Size Fashion"}

Based on the interview, when all respondents were asked about their understanding about Plus Size Fashion, a lot of the respondents relate them with the real condition of personal, physical appearance, product, and business. The understanding here is involving both parts in internal and external which this statement relates to the theory [11] [1] simply a large size in study of specialty size clothing. Besides being related to the understanding in big-clothing concept. The respondents also relate Plus Size Fashion with personal identity. The researcher found that this fashion happened due to self-concept which have two different root causes from physical appearance and those responses from their own. Those two are body positivity and body dissatisfaction.

In term of Plus Size Fashion, there is statement supporting the personal identity with body positivity. The fat bodies acceptance movement and a person's acceptance of a larger body will be defined as 'fashionista', the one who care so much with fashion involvement, materials, and personal appearance [12] [13]. Above statement is not wrong and it surely correlates with statements of respondents where Plus Size fashion simply happened from user's acceptance of their physical appearance combined with urge of their high degree in fashion involvement and personal appearance. It usually can be indicated from those persons who have personal identity with body positivity through their interest more in style, colors, value, despite of only size. While about personal identity with body dissatisfaction, [14] stating that individuals may have chosen a certain type of apparel to hide and camouflage unintended parts of their bodies but mostly they are still interested in clothing and believe which fashion plays important role. The statement supports as if the user who have body dissatisfaction prioritize only how to get fit in fashion and other details are just additions. However, starting from clothing concept and personal identity, both of them are making a new category of fashion. [11] [1] [15] In the plussize consumers' preference for plus-size clothing, size, fit, 
and style seems are always dissatisfied area. It is indicating that plus-size clothing does exist and it has been fashion category that still has problem in it. In addition, from plus size fashion is not one single type, they provide many preferences to suit in plus size user who have many backgrounds.

\section{B. Consumer's Buying Process}

Based on the interview, when all respondents were asked about their buying process for Plus Size Fashion, a lot of the respondents start from what they really need in fashion product. According to the result of respondents above, what they really need is coming from physical appearance that need extra attention for fashion product. The statement of [15] [11] saying that a large proportion of market remains underserved in a variety of ways which means the plus size user's need of fashion is not fully discovered. Therefore, the result of the need of fashion are showing that Top Fashion product such shirt, outer, T-shirt and Bottom fashion product such as chino pants and jeans are what actually plus size product that they really need and those can be resource to maximize market share of plus size fashion business. Furthermore, finding out where to get the product is the next part of buying process. The shopping channel does matter for consumer in the process of buying their fashion product. According to [16] Plus size user disproportionately likes to buy via direct sales channels compared both catalogs and the Internet. That is meant that consumer tend to buy in offline store but the statement is not fully correct because there are still consumers according to the result that they prefer tailoring product and buying in online store for example: top fashion product. Thus, shopping channel here are divided into online store, tailoring, and offline store that have the highest tendency in process of buying. Talking about shopping channel: online, offline, and tailoring, according to the result of interview saying that consumers were experiencing difficulties in buying process of Plus Size Fashion. The statement of [2] saying that the problem is not just with the variety of sizes and styling on offer but rather be like with their role in providing overall fashion content, fit and the shopping environment. So that, it supports the result of interview that shows how plus size user still having constraints such as unavailable size, limited style, low quality materials, poor durability, and pricing.

In the other way, due to constraints faced by Plus Size Consumer, it results some expectation expressed by the respondents. This result is meant to be a condition that needs to be taken look detailer for fulfilling both need of fashion and buying process. The expectations are such as providing many varieties plus size fashion product, exact sizing, price options, and quality warranty. The expectations explored from Plus Size User is not just an expectation because according to [15] a consumer might decide to shop product at store if they feel that these actions are consistent with their own perceptions of themselves which the statement is strongly correct for plus size fashion business to fulfilling what the consumer expect for as priority, so that buying process may have lesser consumer's pains and higher consumer's satisfaction.

\section{Price Consciousness}

There is a difference result in the range of price between product owned and expected product. Thus, in term of price consciousness shows higher buying power that can be afford by plus size user as long as they get what they have expected.
It is supported with statement of [17] which explained higher prices may have influenced consumers' purchase intention because high price is defined as high quality. It is correct according the result of interview, since the respondents are having no problem in the bigger ranger buying power with condition that saying it is suitable to what they expect. Thus, the buying power of plus size user for fashion product is in the range of Rp 300.000-Rp 500.000.

\section{Product-related factors}

To understand about Plus Size Fashion Product, the researcher focuses to Male Plus Size Pants only in this research. About Plus Size Fashion Product, the researcher focuses in detail in order to continue in the next step of financing. From the data obtained related to the male plus size pants, it is therefore continued to decision of the ideal male plus size pant according to plus size user. There are several questions that were used by the researcher to find out the Product-related factor. The questions are about preference of product's type, product's material, product's expectation, colors, supplies,

TABLE 1 THE VISUALIZATION OF PRODUCT-RELATED FACTORS

\begin{tabular}{|c|c|c|c|}
\hline \multirow{4}{*}{$\begin{array}{l}\text { Male Plus } \\
\text { Size Pants }\end{array}$} & $\begin{array}{l}\text { Preference of } \\
\text { product's type }\end{array}$ & $\begin{array}{l}\text { Product's } \\
\text { materials }\end{array}$ & $\begin{array}{l}\text { Product's } \\
\text { Expectation }\end{array}$ \\
\hline & Chino Long Pants & Stretch materials & \multirow{3}{*}{$\begin{array}{l}\text { - Long Lasting } \\
\text { - High Durability } \\
\text { - Soft and Light } \\
\text { Fabric } \\
\text { - Stylish } \\
\text { - Body-Fit }\end{array}$} \\
\hline & Jeans Long Pants & $\begin{array}{l}\text { Stretch and Washed } \\
\text { Materials }\end{array}$ & \\
\hline & Trouser Long Pants & $\begin{array}{l}\text { Stretch and } 100 \% \\
\text { cotton fabric }\end{array}$ & \\
\hline
\end{tabular}

and product's sizing. By asking all questions that relates to the product-related factor, the researcher simplify all of the respondents answer about preference product's type, materials, expectation. From the Table 1, we can see that according to 10 respondents only 3 types of Pants mentioned, 4 people like chino, 3 people likes jeans, 2 people likes trouser, and 1 respondent doesn't care as long as it suits on him. Those types of pants are correlated with its materials. Each type of pants has their own materials preference. While about the product's expectation related to features of pants are just the same for all kind of pants' type. Those respondents, mostly do not have deep understanding about pants' materials but they tend to know what they expect because those coming their concerns in body appearances. Non-product-related Factor

While from 10 respondents, only 4 respondents who concern about product's colors. This product's color is actually related to the decision of product materials. Since cotton fabric has various colors. According to 4 respondents who gave attention to product's colors, they are mostly having same concerns and preference. Pure dark colors and no pattern are intended by plus size user. After talking about the product materials, the respondents are mostly showing attention in product's supplies. Who the producer and where the materials come from are part of their concerns. Local and import are the codes related to product's supplies. From both local and import supplies are chosen by each plus size user related to each quality and what the shopping channel that they frequently visited. However, only two respondents out of ten respondents who care about product's sizing. Both respondents are just talking about type of size and according to all of respondents do not know about the detail size of pants. This result is simply 
a proof that plus size user does not really know about their body's size and it is therefore challenges for plus size fashion business to fulfill product's expectation.

Furthermore, from factors related product found from all respondents, types of pants, consumer's expectation, colors, materials, and sizing are part of plus size user's concern and it is supported by the conclusion of [1] which says that dissatisfaction was greatest related to size availability, pricing, colors, style selection and fit. No matter what, according to the result of interview, there are another two factors mentioned which are materials and supplies related plus size user's concerns. It means, the concern of plus size user is widely diverse and not fully explored.

\section{E. Non-product-related Factors}

Thus, from factors related non-product found from all respondents, types of services are playing important role during buying process and product context. Those services are customer service, direct sizing, customization, free shipping, size details tag, and free cutting. This result is supported by [15] that consumers were not satisfied with the shopping experience because they cannot find the "cute" clothes which is like those in regular sizes. This is meant that consumer need extra service to get satisfied. So that, those services expressed by respondents can be tools to satisfy them. While those insights obtained during interview are bonus to benefit plus size fashion business in process of making strategy. Those insights are converted to be business opportunity because the

\begin{tabular}{|c|c|}
\hline PLUS SIZE FASHION BUSINESS & PLUS SIZE USER \\
\hline \begin{tabular}{l}
\multicolumn{1}{c}{ SERVICES } \\
- Customer service \\
- Direct sizing \\
- Customization \\
- Free shipping \\
- Size details tag \\
- Free cutting
\end{tabular} & \begin{tabular}{ll} 
& \multicolumn{1}{l}{ INSIGHTS } \\
- & Plus Size User's Loyalty \\
- & Big Market Size \\
- & Unwanted Plus Size \\
& Title
\end{tabular} \\
\hline
\end{tabular}

number of plus size user is big, the loyalty of consumer sure can be made as if it is satisfying, and body dissatisfaction does exist so that need to make proper promotion content. This is the visualization of Service and Insights for Plus Size Fashion Table 2.

\section{F. Value Proposition Canvas}

In the value proposition canvas, the researcher finds out that there is task need in the perspective of business player to overcome the customer pain, gain, and job. According to the result of interview, the researcher also finds out detail in the variables of product-related factors and non-product-related factor in order to solve the customer pain, gain, and job. Started from product-related factor the researcher finds according to all respondents' factors needed in product is about the preference of product's type, materials, sizing, colors, expectation, and supplies. While about the non-product related, the researcher finds about the services needed by consumer and business opportunity expressed by consumer in plus size fashion market. Furthermore, from the results of product-related factors and non-product-related factors, the researcher makes the gain creators and the pains relievers and create final product and service. This is aligned with the statement of [18] saying the value proposition is strongly associated with business mode canvas where it is described as the tool how an organization rationally captures, manufactures, and deliver value. Added [18] Value Proposition Canvas helps to an organization in how creating value for your customers and also helps the company design products and services based on their customers want. Hence, here is the value proposition canvas of Male Plus Size Pants explanation in Figure 1.

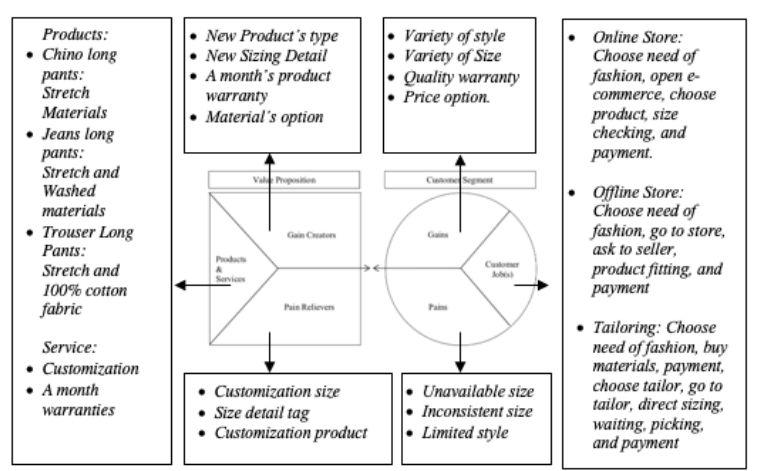

FIGURE 1 THE VALUE PROPOSITION CANVAS

\section{G. Cost Projection}

Hereby, since wants and needs have been explored according to consumers' concern, so the researcher convert it to several costs structure that relate to the products and services focused on Male Plus Size Pants. These prices' references are obtained from the researcher's benchmarking in plus size fashion business.

Furthermore, the researcher creates the initial investment according to the value proposition canvas which correlates to the cost of product and service. This initial investment is used to be fixed cost and to be used to price product before predicting profitability. This initial investment is assumed for three products offered and two services through offline store concept with online platform selling and all the time shipping Table 3 .

TABLE 3 THE INITIAL INVESTMENT

\begin{tabular}{|c|c|c|c|c|c|c|c|}
\hline \multicolumn{8}{|c|}{ Initial Investment } \\
\hline Items & Qty & & Price & \multicolumn{4}{|c|}{ Total } \\
\hline \multicolumn{8}{|l|}{ Equipment: } \\
\hline Telephone & 1 & IDR & $150,000.00$ & IDR & $150,000.00$ & & \\
\hline Laptop & 1 & IDR & $4,000,000.00$ & IDR & $4,000,000.00$ & & \\
\hline Cashier Machine & 1 & IDR & $3,000,000.00$ & IDR & $3,000,000.00$ & & \\
\hline Product's Hanger & 30 & IDR & $7,000.00$ & IDR & $210,000.00$ & & \\
\hline Table & 3 & IDR & $250,000.00$ & IDR & $750,000.00$ & & \\
\hline Chair & 4 & IDR & $50,000.00$ & IDR & $200,000.00$ & & \\
\hline Mirror & 2 & $\mathrm{IDR}$ & $100,000.000$ & IDR & $200,000.00$ & & \\
\hline Meter Rope & 2 & IDR & $20,000.00$ & IDR & $40,000.00$ & & \\
\hline Curtain & 2 & $\mathrm{IDR}$ & $200,000.00$ & $\underline{I D R}$ & $400,000,00$ & IDR & $8,950,000.00$ \\
\hline \multicolumn{8}{|l|}{ Supplies: } \\
\hline Stationary & 1 & IDR & $200,000.00$ & $\underline{I D R}$ & $200,000.00$ & IDR & $200,000.0 \mathrm{C}$ \\
\hline website & 1 & IDR & $2,000,000.00$ & & & IDR & $2,000,000.00$ \\
\hline Site Development & 1 & IDR & $20,000,000.00$ & & & IDR & $20,000,000.00$ \\
\hline \multicolumn{8}{|c|}{ 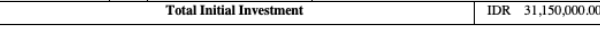 } \\
\hline
\end{tabular}

Based on the product selected which are chino, jeans, and trouser, the researcher create break-down cost to project cost of goods sold Table 3.4. in order to further process which is Pro Forma Statements to see the profitability. The cost all in the COGS Table is variable cost, it assumes that for any increase of sales will impact to increase cost and expense.

As the researcher is projecting in the eye of plus size fashion business's player, so that the researcher creates operating expense for shopping online store with online shopping platform according to the researcher's benchmarking in order to make Pro Forma Statements. The assumption is, for those 
twelve months, there are two months are projected for increased operating expense for $50 \%$ due to Ramadhan Sales and Christmas Sales. Table 3.5 is the Projected Operating Expense.

TABLE 4 THE PROJECTED COGS

\begin{tabular}{|c|c|c|c|c|c|c|}
\hline Items & \multicolumn{2}{|c|}{ Chino } & \multicolumn{2}{|c|}{$\begin{array}{l}\text { Jeans } \\
\end{array}$} & \multicolumn{2}{|c|}{ Trouser } \\
\hline Materials & IDR & $80,000.00$ & IDR & $80,000.00$ & IDR & $60,000.00$ \\
\hline Leather Tag & IDR & $20,000.00$ & IDR & $20,000.00$ & IDR & $20,000.00$ \\
\hline Price Tag & IDR & $2,000.00$ & IDR & $2,000.00$ & IDR & $2,000.00$ \\
\hline Instruction- & & & & & & \\
\hline Tag & IDR & $1,000.00$ & IDR & $1,000.00$ & IDR & $1,000.00$ \\
\hline Shopping Bag & $\mathrm{IDR}$ & $3,000.00$ & IDR & $3,000.00$ & IDR & $3,000.00$ \\
\hline Direct Labor & & & & & & \\
\hline Cost & IDR & $50,000.00$ & out & $50,000.00$ & IDR & $50,000.00$ \\
\hline COGS & IDR & $156,000.00$ & IDR & $156,000.00$ & IDR & $136,000.00$ \\
\hline
\end{tabular}

TABLE 5 THE PROJECTED OPERATING EXPENSE

\begin{tabular}{|l|lr|}
\hline \multicolumn{3}{|c|}{ Projected Operating Expense } \\
\hline Items & \multicolumn{1}{|l|}{ Total } \\
\hline Administration expense & IDR & $260,000.00$ \\
\hline Electricity Bills & IDR & $1,950,000.00$ \\
\hline Telephone Bills & IDR & $1,300,000.00$ \\
\hline Website Domain Bills & IDR & $1,800,000.00$ \\
\hline Offline Promotion expense & IDR & $6,500,000.00$ \\
\hline Rent Space & IDR & $60,000,000.00$ \\
\hline Online Promotion expense & IDR & $3,900,000.00$ \\
\hline Bank Administration expense & IDR & $180,000.00$ \\
\hline Fuel expense & IDR & $6,500,000.00$ \\
\hline Tailor Fee & IDR & $13,000,000.00$ \\
\hline Labor Expense & IDR & $52,000,000.00$ \\
\hline Total & IDR & $\mathbf{1 4 7 , 3 9 0 , 0 0 0 . 0 0}$ \\
\hline
\end{tabular}

Those can be used to project the Pro Forma Statements in order to see profitability analysis in Plus Size Fashion Business. Those expenses and cost are projected according to the product and service needed based on value proposition canvas as the result of interview. For example, the service needed which are customization and one-month warranty, those can be expensed from tailor who is hired for monthly to do customization size or product, or any free cutting service in anytime. While about the gain creators and pain relievers, those have been considered in details of product and services given. So that, the total cost and expense are likely as stated above.

\section{H. Profitability Analysis}

According to the values proposition canvas, the product needed have been known. The total expenses and cost have been stated above. So that understanding the cost through Cost structure is needed to be analyzed again through deciding pricing strategy that is linked to selling price and Pro Forma Statements. Pro statements require income statements and sales forecast can be from past historical data or obtained from the benchmarking of the same type of firm [4].

\section{Pricing Strategy}

Psychological price setting [9] using of number 9 which is so the price drops below a rounded number. The difference between the price 9,99 and 10 is not big and the consumer perceives the difference as being far bigger because by reading from left to right which significantly reduces overall perception of the price. Thus, the researcher finds that according to the result of price consciousness, the plus size user may have buying power from range IDR 300.000 - IDR 500.000 . So that, the researcher concludes the selling price using the maximum buying power because based on data mostly they can also afford that price and according to Lichtenstein et al. (1993) higher prices may have influenced consumers' purchase intention because high price is defined as high quality. Fortunately, the COGS is far below that, also the researcher uses psychological pricing and make it into IDR 499.000 in order to give perception the price is totally below IDR 500.00. So that, once the selling is known, the researcher may have calculated the gross profit and see the profit margin.

\section{Break-even Analysis}

The researcher decided to use the unit contribution method which is actually just a variation of the equation method already described. The approaches put on the idea discussed earlier that each unit sold provides a certain amount of contribution margin which covers fixed cost [4]. For instance, it's a way to how a project could be profitable by equating the total revenues and total expenses. It is comparing the revenues or units that have to be sold to cover fixed and variable costs along with making the sales. So that, the researcher is able to find BEP in quantity, gross profit margin, and profit margin according to the result of value proposition Canvas.

$$
\frac{\text { Fixed Cost }}{\text { Selling Price }- \text { Variable Cost per Quantity }}=\text { BEP }
$$

Each Type Pants are sold with IDR 499.000 for both Chino and Jeans pants have COGS price is IDR 156.000 and for Trouser pants is IDR 136.000. The cost and expense in COGS are all variables and then the average COGS to ease calculation is IDR 149.333 with the initial investment as the fixed cost, so that, the break-even point is:

\section{IDR 31.150 .000 \\ IDR 349.667

$$
=89 \text { pants }
$$

So that, The BEP in units for Male Plus Size Fashion Business according to the value proposition canvas which has 3 different products is 89 units and the gross profit is IDR 349.667 with profit which is as same as contribution margin obtained from selling price less variable cost per unit. The profit margin is therefore calculated into $70 \%$. Therefore, it is simply meant that the margin is relatively big with compared to COGS in it and buying power given. The approach to Break-even points analysis is particularly useful in those situations where a company has multiple product lines and wishes to compute a single break-even point for the company as a whole.

\section{Sales Forecast}

While for projecting the income statement, according to the researcher's benchmarking the vendor used to produce the product as mentioning the COGS, they have capability to produce maximum 200 products per month. Therefore, that number is used to project income statement which per month 200 pieces sold and 300 pieces in two months which is

\begin{tabular}{|c|c|c|c|c|c|c|}
\hline \multicolumn{2}{|l|}{ Unit Sales } & \multicolumn{3}{|c|}{ Rupiahs Sales } & \multicolumn{2}{|c|}{ Total } \\
\hline $\begin{array}{l}\text { Chino Pants } \\
\text { Jeans }\end{array}$ & 1300 & IDR & $499,000.00$ & /units & IDR & $648,700,000.00$ \\
\hline Pants & 780 & IDR & $499,000.00$ & /units & IDR & $389,220,000.00$ \\
\hline Trouser Pants & 520 & IDR & $499,000.00$ & /units & $\underline{I D R}$ & $259,480,000.00$ \\
\hline & & & Tota & & IDR & $297,400,000.00$ \\
\hline
\end{tabular}
Ramadhan and Christmas 50\% increased sales with selling price for 3 types of product is IDR 499,000.00 per each. So

TABLE 6 SALES FORECAST 
that, the total of pants sold is 2600 pants sold and the researcher assumes the proportion number of product sold is $50 \%$ Chino pants, $30 \%$ Jeans, and $20 \%$ Trouser.

\section{A Pro Forma Statements}

The technique used for preparing the pro forma income statement is assumed that all the firm cost and expense are variables. With the same scenario stated in sales forecast where the Sales Revenue is IDR 1.297.400.000 and using the average cost which is IDR 149.333 and addition according to the tax policy of UKM in Indonesia the Tax $0.5 \%$ per month. Thus, this is the pro forma income statement of Male Plus Size Pants in Table 3.7 and The Projected Balance Sheet in Table 3.8 .

TABLE 7 A PRO FORMA INCOME STATEMENT

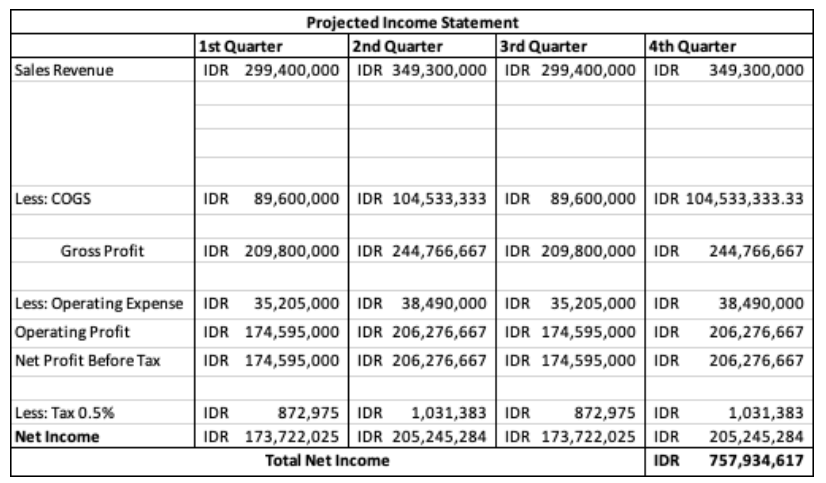

TABLE 8 A PROJECTED BALANCE SHEET

\begin{tabular}{|c|c|c|c|c|c|}
\hline \multicolumn{6}{|c|}{ PROJECTED BALANCE SHEET } \\
\hline & 1st Quarter & 2nd Quarter & & Ird Quarter & 4th Quarter \\
\hline Cash & IDR $173,722,025$ & IDR 205,245,284 & IDR & $173,722,025$ & IDR 205,245,284 \\
\hline Receivables & IDR $\quad-$ & IDR & IDR & - & IDR \\
\hline Tool & $9,150,000$ & $9,150,000$ & IDR & $9,150,000$ & $9,150,000$ \\
\hline Website & $2,000,000$ & IDR $\quad 2,000,000$ & IDR & $2,000,000$ & IDR $\quad 2,000,000$ \\
\hline Site Development & IDR $\quad 20,000,000$ & IDR $20,000,000$ & IDR & $20,000,000$ & IDR $20,000,000$ \\
\hline Total Assets & IDR 204,872,025 & IDR 236,395,284 & IDR & $204,872,025$ & IDR 236,395,284 \\
\hline Account Payable & IDR & IDR & IDR & - & IDR \\
\hline Salaries and wages payable & IDR & IDR & IDR & - & IDR \\
\hline Total Liabilities & IDR & IDR & IDR & - & IDR \\
\hline Share capital & IDR $31,150,000$ & IDR $31,150,000$ & IDR & $31,150,000$ & IDR $31,150,000$ \\
\hline Retainned Earning & IDR $173,722,025$ & IDR 205,245,284 & IDR & $173,722,025$ & IDR 205,245,284 \\
\hline Total Equity \& Liability & IDR 204,872,025 & IDR 236,395,284 & IDR & $204,872,025$ & IDR 236,395,284 \\
\hline
\end{tabular}

\section{CONCLUSION}

Therefore, the researcher recommends Plus Size Fashion Business to shift another pants' type product, yes jeans one of the need of fashion but chino has more role in plus size fashion. For services given, just focus on the customization and quality warranty. Regarding selling platform, the researcher finds out the plus size user prefer offline but there is still possibility to sell online. So that, as if the business has more capital, the researcher suggests to open offline store or at least doing consignment store in order to fulfill the plus size user insecurities. In addition, as if the business wants to stay online basis, they may lower the price since the COGS found is quite small in order to gain attention for plus size user.

\section{REFERENCE}

[1] Hathcote and M. K. O. Kind, "Speciality-size college females: satisfaction with retail outlets and apparel fit," Journal of Fashion Marketing and Management: An International Journal, pp. 315-324, 2000 .

[2] R. Otieno, C. Harrow and G. Lea-Greenwood, "The unhappy shopper, a retail experience: exploring fashion, fit and affordability," International Journal of Retail \& Distribution Management, 2015.

[3] Z. Tamer, "A Protocol for Data Collection and Analysis of Profitability for Construction Companies," PURDUE UNIVERSITY GRADUATE SCHOOL, West Lafayette, 2009.

[4] L. J. Gitman and Zutter, Principles of Managerial Finance Fourteenth Edition, New York: Pearson, 2016.

[5] P. L. \&. A. T. M. Saunders, Research methods for business students, Pearson Education, 2009.

[6] J. W. Creswell, Qualitative inquiry and research design: Choosing among five tradition, Pearson Education, 1998.

[7] J. L. \&. F. M. K. Bergström, Brand Management: A Qualitative study on Branding in a SME, 2010.

[8] J. Y. Chung, J. Lee and R. L. Heath, "Public relations aspects of brand attitudes and customer activity.," in Public relations aspects of brand attitudes and customer activity., Public Relation Review, 2013, pp. 432-439..

[9] G. Foxall, R. Goldsmith, R. E. Brown and S, Psihologija potrošnje u marketingu., Jastrebarsko: Naklada Slap, 2007.

[10] R. Garrison, in Managerial Accounting Fifteen Edition, New York, 2016, p. 187.

[11] U. Chowdhary and N. V. Beale, "Plus-size women's clothing interest, satisfactions and dissatisfactions with ready-to-wear apparel.," Perceptual and Motor Skills, pp. 783-788.

[12] S. Murray, (Un/be) coming out? Rethinking fat politics, Social Semiotics, 2005.

[13] R. Puhl and K. D. Brownell, Bias, discrimination, and obesity, Obesity research, 2001.

[14] J. Trautmann, S. L. Worthy and K. L. Lokken, " Body dissatisfaction, bulimic symptoms, and clothing practices among college women," The Journal of Psychology, pp. 485- 498., 2007.

[15] M. Wang, "The U.S. Plus-size Female Consumer: Self-Perception, Clothing Involvement, and the Importance of Store Attributes.," UMI, p. 199, 2007.

[16] L. Arons, "Does TV viewing influence store image and shopping frequency?," Journal of Retailing, pp. 1-13., 1961.

[17] D. R. Lichtenstein, N. M. Ridgway and R. G. Netemeyer, "Price perceptions and consumer shopping behavior: A field study," Journal of marketing research, p. 234 - 245., 1993.

[18] A. Osterwalder, T. Pigneur, T. Clark and A. Smith, Business model generation: A handbook for visionaries, game changers, and challengers, Wiley, 2010.

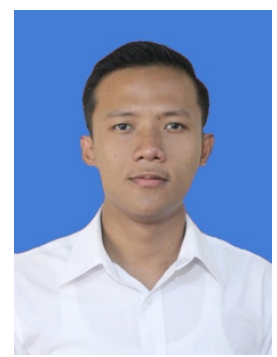

Ilham Pristaka Yudha was born in Magetan, $7^{\text {th }}$ of June 1997. He graduated from Sampoerna Academy for High School Level in Jakarta 2016. Then, he continues his study in School of Business and Management, Institut Teknologi Bandung, majoring entrepreneurial studies. He has professional experience in running his own business in fashion and entertainment show industry. 


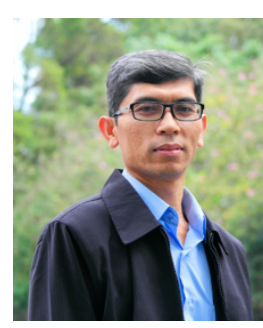

Acip Sutardi is a Senior Lecturer at the School of Business and Management, Bandung Institute of Technology (SBM-ITB). $\mathrm{He}$ is also a member of Business Risks and Finance expertise group. He earned a master's degree in Accounting from the University of Padjadjaran Bandung. He also holds a Bachelor's degree in Accounting from Tridharma School of Economics, Bandung. He has more than 15 years of teaching experience in Financial Accounting. He also has experience as an auditor, in preparation of financial statements and Accounting Information Systems. He was a consultant at the Ministry of National Education of Indonesia in the field of Government Accounting. Acip's research interest are Islamic Accounting, Behavioral Accounting, Auditing and Professional Ethics, Taxation, and Voluntary Disclosure.

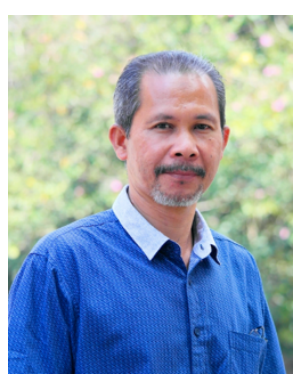

Asep Darmansyah is a Lecture at the School of Business and Mangement, Institut Teknologi Bandung. He is also a member of business risk and finance expertise group. He received his bachelor Master Degree in University of Padjajaran Bandung. He earned his Bachelor degree in Bogor Institure of Agricultural. He has more than 18 years of experiences in Financial Accounting. He also has experience as an internal auditor, and preparation of Financial Statements. 